\title{
Project Management Office Strategies of Hosting Indonesia National Olympic Games (PON) XIX/2016 in West Java
}

\author{
Yudha Munajat Saputra*, Sandey Tantra Paramitha \\ Faculty of Sport and Health Science Education \\ Universitas Pendidikan Indonesia \\ Bandung, Indonesia \\ *yudhamsaputra@upi.edu, sandeytantra18@upi.edu
}

\begin{abstract}
With West Java about to host the National Olympic Games of Sport 2016. Therefore, this study begins by problematic the nation of sport multi events and the benefits. They are intended to bring to hosts. The study serves as a general introduction to papers that follow in this special issue. This study aims to explore strategies of West Java as a host of National Olympic Games XIX/2016. This study uses Project Management Office (PMO) to support the strategy operationalization using improvement the multi events of sport. Research method in depth interview data were collected from a few stakeholders related to sport events. The qualitative data were analysed to understand the impact of PMO strategies on success a host of National Olympic Games 2016 in West Java. Thus, this study serves as a discussion of some of the key concepts in, and assumptions about the use of PMO strategies to produce a legacy for the hosting province. From data that we found, we can conclude that PMO is the most important key from hosting National Olympic Games of Sport 2016.
\end{abstract}

Keywords: hosting, legacy, multisport events, project management office, strategies, West Java Province

\section{INTRODUCTION}

The holding of the National Sports Week (PON) is the Indonesian government's agenda in the field of sports which is held every 4 years [1]. The PON was first held in the city of Solo in 1948, continued in Medan in 1953 and Makassar in 1957 with the theme "safeguarding the independence, unity and integrity of the Indonesian nation." The next PON was held in Jakarta until 1996. In an effort to equalize sports development, the government the centre began in 2000 and the administration of the PON was returned to the provincial government.

\section{A. PON XV 2000 East Java}

In 2000 East Java was appointed as the host of the XV PON with the theme "Adhesives of the Unity of the Nation" In general, the implementation of PON in East Java was wellimplemented and successful. The construction of sports facilities is spread in 5 regencies / cities, with standard sports achievements that are not special. In organizing it is still not optimal from opening, implementation to closing. There is nothing special, however, the host of East Java has left a memorable ending event and there are no problems, like in the PON - PON that had been done before.

\section{B. PON XVI 2004 Palembang}

In 2004 Palembang hosted the XVI PON with the theme, "United Unity". All PON events are centred in the city of Palembang. Preparation and organization are considered weak, so that the KONI Centre must intervene. PON has not yet seen any link with efforts to increase investment, trade and tourism. Promotion of events in print and electronic media is still very minimal, so that many people do not know when the PON will be held. In fact there are some obstacles that are not ready for the facilities and infrastructure needed for the biggest national sporting event. In conclusion, the implementation of the PON in Palembang did not satisfy all the contingents.

\section{PON XVII in 2008 East Kalimantan}

In 2008, East Kalimantan Province was chosen as the host of the holding of PON XVII with the theme, "Achieving Sturdy Achievement of Brotherhood." Competition and competition activities were carried out in several Regencies / Cities. Preparation and organization are considered too many interventions by people who are not experts in sports, so that there are many obstacles faced at that time, especially the chaotic transportation services. Not involved in some areas of the 2008 PON XVII 2008. Lack of PON Advertising and media exposure. Some infrastructure constraints occurred

\section{PON XVIII 2012 Riau}

The 2012 PON XVIII was held in Riau with the theme, "PON Glow." Focused on various regions or regions in Pekan Baru Riau. Preparation and organization are considered weak, and slow due to careful preparation of facilities and infrastructure so that many obstacles faced at that time were more complex, including lodging, until transportation was erratic at that time. The lack of maximum PON echoes in several regions, up to the Centre in relation to the 2008 PON XVII event both print and electronic media. Lack of PON Advertising as well as media exposure and several infrastructure constraints occur 
The implementation of PON to PON is very expensive when the organizing activities are held outside Jakarta, because it does not require a large and large cost to build the infrastructure, physical, transportation, accommodation, accommodation, as well as ceremonial opening events and ceremonial closing events.

PON tends to be a "Project" that is detrimental and has a variety of problems, and leaves debt and does not have a significant further impact on regional development, as well as other sports athletes who have performed well and are struggling for their province and tend to only get promises. Facilities \& Infrastructure that are built with large investments tend to be less effective when post-PON ends, making it wasteful and a burden for the Regional Government.

In 2016 West Java was chosen as the host of PON XIX with the theme, "victorious in the land of legend". PON West Java prepares itself from the preparation period, the implementation period, until after the implementation [2]. The target of West Java as the host of PON XIX is to want to achieve chess success in PON XIX in 2016, namely (1) successful achievement means the creation of young athletes with high talent and able to break various national and world records. According to Saefudin West Java's success was ranked top with $28.5 \%$ of the total 756 gold medals contested by 34 provinces [3]; (2) successful implementation means the success of the province of West Java as the host of PON is expected to be able to build a building image as the organizer of the best and professional multi-sport events; (3) the success of community economic empowerment means the success in carrying out the 2016 PON XIX relay task as an initial milestone in the renewal of the PON event in Indonesia to be of economic value; and (4) administrative success means the success of West Java in organizing PON without the occurrence of financial administration problems that lead to violating the law.

West Java PON XIX expectation in 2016 is not only from West Java Province, to be better, even various levels of society from other regions and provinces, hoping that the implementation of PON to XIX in 2016 can really realize a building image event that is more good and accountable, professional, and can create a sparkling sporting event that is felt by all levels of society from various regions, especially also West Java. As the host of the XIX PON, starting in 2010 West Java has made preparations, especially facilities and infrastructure events, both through various print and electronic media.

With particular hope for all levels of society in West Java Province that the 2016 PON XIX Grand Committee starting from the Chairperson and Chairperson and Chairperson of the Daily or National Committee can truly synergize and commit to jointly succeed the PON XIX event. Therefore, the West Java Provincial Government began in 2013 to implement a strategy that had never been carried out in the previous PONPON. By appointing a Project Management Office (PMO), it is hoped that the successful chess launched by the West Java Provincial Government can be realized [4]. This success is expected to be a model for the implementation of the upcoming PON-PON.
PON tends to be a "Project" that is detrimental and has a variety of problems, and leaves debt and does not have a significant further impact on regional development, as well as other sports athletes who have performed well and are struggling for their province and tend to only get promises. Facilities \& Infrastructure that are built with large investments tend to be less effective when post-PON ends, making it wasteful and a burden for the Regional Government. National Olympic Games of Sport in Indonesia can we make comparison with the world Olympic Games of Sport, as said by Agha, The International Olympic Committee (IOC) requires cities that bid for the Olympic Games to formulate a legacy strategy [5]. This case follows a sport professional tasked with developing an Olympic bid for their city. Specifically, the case considers various legacy outcomes including: destination image, tourism, cost, venues, housing, and social legacies. The case is written with anonymity of the actual city so that the instructor can adapt the case to a specific city. The case is particularly useful for courses covering sport tourism, stakeholder management, event management, or sport economics and finance.

\section{METHOD}

In accordance with the problems examined in the field study, qualitative research is used. According to Ary, qualitative research is a series of scientific processes in the social field that study the complexity of behavioural and social phenomena [6]. The purpose of qualitative research is directed at efforts to describe what is happening and interpret the description in clear language so that events what happened can be illustrated carefully and accurately. In qualitative research there is no manipulation of the dependent variable, because it is not carried out under controlled conditions as in quantitative research. In addition, the data generated is not in the form of numbers, but descriptive data in the form of written or verbal words from people and observed behaviour.

With this qualitative study, researchers are expected to be able to interpret data and present the results of strategies for success at the 2016 PON XIX in West Java. As Denzin and Lincoln describe, in qualitative research the notes and interpretations are based on field findings [7]. The field findings are further reviewed to obtain a more accurate meaning. Mikkelsen's opinion states that, qualitative methods are identified with phenomenological and interpretative research [8]. Phenomenological approaches lead to the dual focus of observation, namely: (1) what appears in the experience, which means that the whole process is the object of study and (2) what is directly provided in the experience is directly present for those who experience it.

In general, qualitative methods have more characteristics in accordance with the phenomena that develop in the field of education, social, and psychological. This is because the study design in qualitative research is more flexible. That is, modifications can be made even though research is being carried out. In addition, researchers can relate directly to the object of their study in a more conducive relationship atmosphere, as well as the need for research costs using qualitative methods in general are relatively more efficient, and others. During this qualitative method is considered to have the 
- Secretariat Division

power to answer research questions more broadly and deeply. Hyllegard, et al. explains that, qualitative research methods give researchers the possibility to find out more broadly and deeply about the complexity of social phenomena [9]. Likewise in the context of physical education and sports, especially to better appreciate the position of sports and training in a diverse range of cultures and values. In the process of qualitative research is always open, meaning that improvements and improvements can be done when the process takes place. Therefore in qualitative research, the process is as important as the results to be achieved, even according to Bogdan and Biklen, qualitative research places more emphasis on process rather than results [10].

So, the data collection techniques used in this study is intended to obtain various information that mutually support and complement each other. Data is collected from research subjects based on: (1) observation guidelines, (2) interviews, (3) document review. To get the truth of the data done by triangulation and consistency test between the PON Large Committee, West Java KONI and PMO [11].

\section{RESULTS}

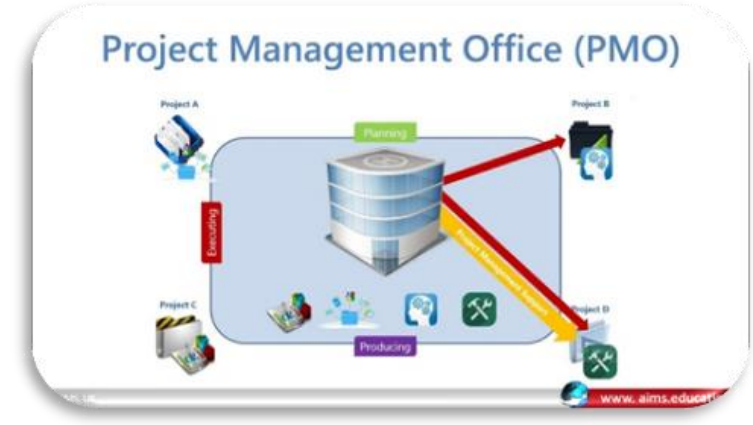

Fig. 1. Project Management Office (PMO).

Project Management Office is a division or department within an organization that determines and maintains standards in project management in that organization. The main purpose of establishing a PMO is to get the maximum benefit by standardizing and disciplining projects according to certain regulations, processes and methods [12].

The findings are something that is obtained from the field in the form of answers from various research data sources. The data analysis, according to Patton, is the process of arranging the order of the data, organizing it with interpretation, which gives a significant meaning to the analysis, explaining the description patterns, and looking for relationships between the dimensions of the description [13]. So, the results and analysis of collected data obtained from the results of the field notes are carefully organized to answer the research question, namely: how is the PMO strategy in the successful implementation of PON XIX in 2016 West Java?

Based on the results of data processing and other support in the field that has been documented as follows:

- At the planning stage the PMO has made preparations by forming the implementing fields of 2016 PON XIX along with TUPOKSI and SOP consisting of:
- Regional Relations and Protocol

○ Fields of Registration and Accreditation

○ Information and Communication Technology

- Accommodation and Consumption

- Transportation Sector

○ Ceremony Field

- Fields of Media Broadcasting Services

○ Security Sector

- Marketing, Funding and Business

○ Human Resources Sector

○ Fields of Match

- At the PON implementation stage, the PMO has conducted based on the baseline of the field activities [14]. Each field understands what activities must be carried out in the relevant month. If the activity cannot be carried out, the activity will be carried out as much as possible in the following month so that there will be no accumulation of activities at the end of achieving the baseline. Overall activities that must be carried out in general by PB PON XIX 2016 West Java for the implementation of PON have been carried out well. There were no significant changes between the achievements of key dates until the end of the PON implementation. PB PON XIX 2016 West Java has carried out 49 out of 49 all mandates of activities which were charged or reached $100.00 \%$

- At the reporting stage of the implementation of PON XIX 2016 West Java, the PMO has submitted a report after the implementation of PON XIX 2016 West Java in accordance with the 2016 Field Activities Baseline at the end of December 2016, it seems that the achievement of activities in each field has been completed $(100 \%)$. The activity that has not been carried out is the final review report. Compilation of the final report and accountability for the implementation of PON XIX 2016 West Java with a focus on the preparation of the report include: (1) Executive Report on the Implementation of PON XIX 2016 West Java; (2) Report on the Implementation of PON XIX 2016 West Java; (3) Final Report on Activities: PON XIX 2016; and (4) PB PON XIX 2016 Financial Report.

The relevance of this research as has been studied by Parent, the purpose of this paper was to examine the theory and practice of knowledge management processes, using the Olympic Games as the empirical setting and the Olympic Games Organizing Committee and its stakeholders as participants [15]. The case study of the 2010 Vancouver Olympic Winter Games was inductively and deductively content analysed, resulting in the development of a knowledge management and transfer process model for Olympic Games organizing committees and their stakeholders. Moreover, we found that the information and knowledge concepts should be 
PON XIX which continues to be fostered and fostered in every stakeholder have an impact on the realization of work team solidity.

With the successful implementation of West Java 2016 PON XIX, we recommend to other provinces that will host PON in the future to use the PMO strategy as a companion before, during, and after PON implementation.

\section{REFERENCES}

Based on the results of the analysis and discussion it can be concluded that the Project Management Office (PMO) strategy adopted by the Government of West Java Province in organizing the 2016 PON XIX is very effective [16]. This is evidenced by the average achievement of $100.00 \%$ of all activities contained in the baseline of activities in all fields. This shows that PB PON XIX 2016 WEST JAVA at the end of its implementation has successfully held multi-PON events to XIX in 2016 with the achievement of: (1) Successful Implementation; (2) Success Achievement; (3) Democratic Economic Success; and (4) Successful Administrative Order.

\section{ACKNOWLEDGMENT}

Several factors that have contributed to the successful implementation of West Java 2016 PON XIX include:

- The production of LoG work packages is carried out by the PDU Sector.

- Distribution and installation of LoG at each venue and at specified pairs of points.

- Setup the Command Centre, Head Quarter and Media Centre. Although it is fully implemented by PT TELKOM through sponsorship, so that the ICT Sector can continue to facilitate licensing needs so that the installation of ICT devices can be carried out

- Repetition of simulation of the implementation of crosssector activities including PON fire parade, reception pickup, contingent distribution, contingent flag raising, closing opening ceremony, sports branch competition, organizing exhibitions and side events, broadcasting, publication and media services, business fund marketing, call operations centre, head quarter, command centre and media centre.

- Comprehensive cross-sectional coordination, synchronization and communication so as to grow common understanding in the implementation of crosssectional activities. Concern and a strong sense of ownership over the implementation of West Java 2016
[1] L.W. Aarssen and L. Crimi, "Legacy, leisure and the "work hard-play hard' hypothesis," The Open Psychology Journal et al., Searching for God: Illness-related mortality threats and religious search volume in Google in 16 nations, Personal, Soc, Psychol, Bull, 2016.

[2] D. Ramdhan, Manajemen Event Pertandingan Olahraga. Bandung:

[3] A. Saefudin, Menuju Jabar Kahiji Jabar Ngahiji: Sebuah Refleksi Manajemen Olahraga Kontemporer, Jakarta: Gramedia, 2017.

[4] A. Monteiro, V. Santos and J. Varajão, "Project Management Office Models - A Review," in Procedia Computer Science, 2016.

[5] N. Agha, S. Fairley and H. Gibson, "Considering legacy as a multidimensional construct: The legacy of the Olympic Games," Sport Manag. Rev, 2012.

[6] D. Ary, L.C. Jacobs and A. Razapivich, Introduction to research in education. Philadelphia: Horcourt Brace College Publishers, 1990.

[7] N.K. Denzin and Y.S. Lincoln, Introduction: entering the field of qualitative research. Handbook of qualitative research. Thousand Oaks, CA: Sage, pp. 1-17, 1994

[8] T. Mikkelsen, "Correlation between magnetic resonance spectroscopy imaging and image-guided biopsies: semiquantitative and qualitative histopathological analyses of patients with untreated glioma," Neurosurgery, vol. 49(4), pp. 823-829, 2001 Admissions and the Life Chances of the Disadvantaged. Yale University Press, 92A Yale Station, New Haven, CT 06520-9040, 1996.

[10] R.C. Bogdan and S.K. Biklen, Qualitative research for education: an introduction to theory and methods. Boston, Massachussets: Allyn and Bacon, Inc, 1982.

[11] E.G. Too and P. Weaver, "The management of project management: A conceptual framework for project governance," Int. J. Proj. Manag, 2014.

[12] K. Burgher and M. Snyder, Building a Project Management Office. Coll. Univ, 2013.

[13] M.Q. Patton, How to use qualitative methods in evaluation. no. 4, Sage, 1987.

[14] C. Desmond, "Project management office," IEEE Engineering Management Review, 2015.

[15] M.M. Parent, D. MacDonald and G. Goulet, "The theory and practice of knowledge management and transfer: The case of the Olympic Games," Sport Manag, Rev, 2014.

[16] E.J. Darling and S.J. Whitty, "The project management office: it's just not what it used to be," International Journal of Managing Projects in Business, 2016. Dispora Jawa Barat, 2018

[9] Lavin, E. David and D. Hyllegard, Changing the Odds. Open 